\title{
INTEGRATING DIGITAL TECHNOLOGIES IN BRAZILIAN ENGLISH LANGUAGE TEACHER EDUCATION THROUGH BLENDED LEARNING
}

\author{
ANA RACHEL MACEDO MENDES ${ }^{1}$ \\ ORCID: https://orcid.org/0000-0002-4359-1109 \\ KYRIA REBECA FINARDI ${ }^{2}$ \\ ORCID: https://orcid.org/0000-0001-7983-2165
}

\begin{abstract}
This paper aims at reflecting upon the integration of digital technologies in the form of blended learning (BL) approaches in Pre-service English Language Teaching (ELT) Education. With that aim, a BL approach was designed and implemented in a pedagogical intervention carried out in the form of an action research in a pre-service ELT practicum course in a federal university in Brazil. Data includes questionnaires and interviews administered to the pre-service English teachers and observations carried out in the practicum course. The analysis of data suggests that despite little involvement in the online environment, the BL approach was able to promote critical reflection on the integration of digital technologies in ELT. Moreover, it showed that pre-service teachers' views of the educational value attributed to the online environment and professors' readiness to offer varied and innovating learning options may determine the success of the integration of digital technologies in BL outcomes. The study concludes that the implementation of BL approaches in pre-service ELT education provides a space for reflection on action fostering informed pedagogical decisions regarding the integration of digital technologies in ELT.
\end{abstract}

Keywords: Blended learning, pre-service english language teacher education, digital technologies.

\section{INTEGRANDO TECNOLOGIAS DIGITAIS NA FORMAÇÃO INICIAL DE PROFESSORES DE INGLÊS POR MEIO DE ABORDAGENS HÍBRIDAS}

RESUMO: Este artigo tem como objetivo refletir sobre a integração de tecnologias digitais por meio de abordagens híbridas na formação inicial de professores de inglês. Para tanto, uma proposta de abordagem híbrida foi projetada e implementada como intervenção pedagógica na forma de uma pesquisa-ação em uma disciplina do curso de formação inicial de professores de inglês em uma universidade federal do Brasil. Os dados incluem questionários e entrevistas administradas aos professores de inglês em préserviço e observações realizadas durante a disciplina de estágio curricular. A análise dos dados sugere que, apesar do pouco envolvimento no ambiente online, a abordagem foi capaz de promover uma reflexão crítica sobre a integração de tecnologias digitais no ensino de inglês. Além disso, mostrou que as visões dos professores em pré-serviço a respeito do valor educacional atribuído ao ambiente on-line e a

\footnotetext{
1 Universidade Federal do Espírito Santo, Programa de Pós-Graduação em Educação. Vitória, ES, Brasil. <anarachel.mm37@gmail.com>

2 Universidade Federal do Espírito Santo, Departamento de Linguagens, Cultura e Educação. Vitória, ES, Brasil. $<$ kyria.finardi@gmail.com >
} 
preparação dos professores para oferecer opções de aprendizado variadas e inovadoras podem determinar o sucesso da integração de tecnologias digitais por meio de abordagens híbridas. $\mathrm{O}$ estudo conclui que a implementação de abordagens híbridas na formação inicial de professores de inglês em préserviço oferece um espaço para reflexão sobre ações que promovam decisões pedagógicas informadas sobre a integração de tecnologias digitais no ensino de inglês.

Palavras-chave: Abordagens híbrida, formação inicial de professores de Inglês, tecnologias digitais.

\section{INTEGRANDO TECNOLOGÍAS DIGITALES EN LA FORMACIÓN DE PROFESORES DE INGLÉS EN BRASIL A TRAVÉS DEL APRENDIZAJE HÍBRIDO}

RESÚMEN: Este estudio tiene como objetivo reflexionar sobre la integración de las tecnologías digitales a través del aprendizaje híbrido en la formación de profesores de ingles. Para esto, se diseñó e implementó un abordaje de aprendizaje híbrido por medio de una intervención pedagógica llevada a cabo en forma de una investigación-acción en una asignatura de prácticas en el curso de formación de profesores de inglés en una universidad federal de Brasil. Los datos incluyen cuestionarios y entrevistas administradas a los estudiantes del curso y observaciones realizadas en el curso práctico. El análisis de los datos sugiere que, a pesar de la poca participación en el entorno on-line, el abordaje pudo promover una reflexión crítica sobre la integración de las tecnologías digitales en la enseñanza de inglés. Además, demostró que las opiniones de los estudiantes sobre el valor educativo atribuido al entorno on-line y la preparación de los profesores para ofrecer opciones de aprendizaje variadas e innovadoras pueden determinar el éxito de la integración de tecnologías digitales en el aprendizaje híbrido. El estudio concluye que la implementación de abordajes de aprendizaje híbrido en la formación de profesores de inglés proporciona un espacio para la reflexión acerca de acciones que fomentan decisiones pedagógicas informadas con respecto a la integración de tecnologías digitales en la enseñanza de inglés.

Palabras clave: Aprendizaje híbrido, formación de profesores de Inglés, tecnologías digitales. 


\section{INTRODUCTION}

In the current scenario of cultural hybridity and globalization that we live in, digital technologies have increasingly taken up the role of mediators for various activities of daily life, often transforming the way we do things. As many other areas of knowledge, English Language Teaching (ELT) and learning has changed as a consequence of digital technologies and its possibilities for ubiquitous learning (CÁRDENAS-ROBLEDO; PEÑA-AYALA, 2018). Specially after the advent of the internet with its wider access to authentic interactions and contents online, it has been changing the role of teachers (as content providers and gate keepers for interactions in English), and students (as passive receivers of contents delivered by teachers).

Although some teachers integrate digital technologies in their practice, most do so only peripherally as support (FINARDI; PORCINO, 2014) and many are still skeptical about the incorporation, not only of digital resources, but especially of the new educational concepts afforded by the digital age. One reason for that is related to the lack of incorporation of digital technologies and discussions about their role in teacher education (ARRUDA, 2013). Another reason, no less important, specially in contexts such as the one of this study, in Brazil, is related to the lack of infrastructure needed to ensure the integration of digital technologies and their values into pedagogical practices (FADINI, 2016).

Given this scenario, one alternative to include digital technologies in teacher education is to use blended learning approaches (GRAHAM, 2006, DZIUBAN et al., 2018) that combine face-to-face and online instruction to integrate new technologies into educational practices. Although blended learning (BL) has been found to enhance interaction in the target language (FINARDI; PORCINO, 2014), it seems that it has not yet significantly been integrated in pre-service ELT in Brazil. So as to fill in this gap, the present study aims at refleting upon the integration of digital technologies in the form of a BL approach in Pre-service ELT pursuing the following research question: How can BL contribute to pre-service ELT?

\section{EDUCATION AND DIGITAL TECHNOLOGIES}

Digital technologies have enabled the shortening of spatiotemporal distances and the constant crossroads among cultures, identities and discourses (LANKSHEAR; SNYDER; GREEN, 2000). Yet, one of the difficulties of integrating digital technologies into education is the limited availability of digital resources in Brazilian educational institutions, as reported in research ${ }^{3}$ that shows that when available in public elementary schools, the use of technological resources is controlled and restricted. These restrictions may hamper the integration of digital technology in public education widening the digital gap between formal education and everyday life. School access to internet can foster the development of individual's autonomy in search for information (FINARDI; PREBIANCA; MOMM, 2013) to narrow the digital gap (RADA, 2004).

However, it is not enough to offer internet access, education needs to deconstruct 'informationalisation' ideologies (LANKSHEAR; SNYDER; GREEN, 2000) that focus on the use of digital technologies to seek and gather information (only). Rather, the use of digital technologies should be done in one's favor (LANKSHEAR; SNYDER; GREEN, 2000) or in the favor of communities through the building of social capital (WARSCHAUER, 2004).

Yet, research in Brazil has shown (e.g.: TEIXEIRA; FINARDI, 2013; FERRAZ, 2014) that although digital technologies are used in Brazilian English classrooms, it is so mostly instrumentally without critical appreciation and/or appropriation of the social and cultural dimensions and practices afforded by them (LANKSHEAR; SNYDER; GREEN, 2000). Regarding teacher education, Fadini (2016) found that pre-service ELT teachers do not appropriate the new social practices afforded by

\footnotetext{
3 Research out by the British Council, available at https://www.britishcouncil.org.br/sites/default/files/estudo_oensinodoinglesnaeducacaopublicabrasileira.pdf (last access in February 2020)
} 
digital technologies using them mostly as a pedagogical support rather than as a central part of their practice.

\section{TEACHER EDUCATION IN THE DIGITAL AGE}

Merlo and Ferraz (2016) suggest that pre-service teacher education should incorporate critical literacy practices going beyong what Monte Mór (2009) calls the superficiality of pedagogical practice with its technicist, instrumental, method-centered approach and reproductive goals. So as to do that, Arruda (2013) suggests profound changes in pre-service teacher education courses to incorporate digital technologies not only as mediators, but also as objects of discussion. In line with that, Paiva (2013) proposes the incorporation of digital technologies by pre-service teacher educators, creating courses that use and discuss digital technologies.

Fadini (2016) carried out a study in the same ELT course where the present study was carried out and concluded that the ELT curriculum there did not include subjects or contents for the discussion of digital technologies, rather that inclusion was left for the discretion of professors. The lack of integration of digital technologies in pre-service teacher education contributes to a deficiency in their digital literacy and practice, thus hampering teaching practices. One alternative to counteract the lack of integration of digital resources in teacher education is to use blended learning approaches.

\section{BLENDED LEARNING}

Blended learning or BL has become popular due to its promise to improve learning through digital technologies in a cost-effective manner (MATHEOS; DANIEL; MCCALLA, 2012; GRAHAM; WOODFIELD; HARRISON, 2013). Yet, focusing only on its cost-benefit means ignoring the other possibilities that this approach affords. For example, BL has shown to contribute to motivation by allowing students to gauge their learning according to their personal preferences and needs (MATHEOS; DANIEL; MCCALLA, 2012). It also promotes learners' autonomy over their own learning time and pace (JOHNSON et al., 2015).

According to Graham (2006), a successful BL approach offers at least three advantages: 1) more active and collaborative student learning; 2) broadening access to education by offering a balance between flexibility (in choosing when and where to study) and human interaction; 3) more profitable for the institution due to the broader audience and more economical due to the decrease in classroom hours. Similarly, Matheos, Daniel and McCalla (2012) also mention some advantages that BL can offer students: greater flexibility in the distribution of materials; broader and faster access to learning, interaction and support between peers and teachers, weaker limits of time and physical space; face-to-face social interaction with independent, personalized online learning.

Graham, Allen and Ure (2005) point out that BL approaches render learning more comfortable and effective contributing to blurring the boundaries between face-to-face and online education which, historically, were two contexts considered separately because of their different methods and target audiences. Notwithstanding these advantages, we think that the results of BL initiatives largely depend on their purpose, planning and implementation.

One issue, paramount for Whittaker (2013), is the context in which BL approaches will be implemented for BL is essentially contextual, and its purposes vary mainly according to the objectives of each situation. As a highly contextual approach, there is no recipe for BL and so studies such as the present one, offer important insights into the design and implementation of BL courses and its implication for teacher education and practice.

We know that there are many challenges to integrate digital technologies in BL approaches, but considering its potential benefits, specially in terms of expanding opportunities for interaction and communication beyond the classroom walls, optimizing contact with the target language in online social practices, BL should be considered in ELT courses and practices. Following that, we believe BL should have its space in pre-service teacher education to guarantee that future teachers are familiar with this approach thus integrating digital technologies in their practice. 


\section{BLENDED LEARNING AND ELT EDUCATION}

Keengwe and Kang (2013) point out the importance of establishing clear rules regarding participation and interaction for both environments but especially for the online environment, where the interaction between people from different contexts is intensified. As reported by Gruszczynska, Merchant and Pountney (2013), pre-service teachers seem to feel uncomfortable to share their productions and experiences online regardless of whether they are good or bad, for lack of trust in those who will have access or for fear of negative feedback. In a closed community, such as those envisioned in BL approaches to teacher education, these fears are alleviated as trust is greater among participants. As such, the online environment of a face-to-face classroom may seem like a good space for peer sharing. BL approaches can also foster autonomy (WHITTAKER, 2013), self-discipline and self-motivation to seek constant updating (KENGWEE; KANG, 2013) concerning changes in language, teaching, education, technologies and society.

Given the potential of BL approaches to the integration of digital technologies in pre-service ELT education, this study aims to analyze the design and implementation of a BL approach in an ELT education course in Brazil. To this end and in what follows, the methodology employed in the study is described.

\section{METHODOLOGY}

In order to investigate how BL can contribute to ELT education, an action research (NORTON, 2018) was carried out in the English Practicum Course of a federal university in the southeast of Brazil. The pedagogical intervention carried out through an action research was developed in three stages that aimed to plan, implement and analyze a BL initiative in the ELT practicum course taught by the authors of this paper who were in charge of the discipline of ELT Practicum acting as teachers-researchers, as shown in Table 1.

Table 1: Study Design

\begin{tabular}{|l|l|}
\hline \multicolumn{1}{|c|}{ Stage } & \multicolumn{1}{c|}{ Activities } \\
\hline Stage 1: Planning & $\begin{array}{l}\text { Recognition through literature review on the approach, course program, } \\
\text { participants and their habits and knowledge regarding digital technology. At this } \\
\text { stage, participants answered questionnaires and professors outlined and discussed } \\
\text { the activities. }\end{array}$ \\
\hline Stage 2: Implementation & $\begin{array}{l}\text { Creation of the online environment, inviting participants, posting activities, } \\
\text { mediating interactions, monitoring (observing interactions). }\end{array}$ \\
\hline Stage 3: Assessment & $\begin{array}{l}\text { Questionnaires about participant and teacher impressions, analysis based on survey } \\
\text { data. }\end{array}$ \\
\hline
\end{tabular}

Source: the authors'

The ELT practicum course where the BL approach was implemented focuses on the observation, experience and analysis of ELT teaching practices in Brazilian Primary Public Schools. The course has 200 hours made up of 120 hours of practice (in primary public schools) and 80 hours of planning, lectures and discussions at the university. The practicum course is offered in the 7th and 8th semesters of the 4-year teaching degree course. The action research was carried out in 2016 by the two authors of this study, acting then as supervising professor and professor assistant in that course.

For the purpose of this study and the BL intervention carried out in the ELT practicum course, the hours of classes were shared between face-to-face and online lessons. Also, the course was divided into three modules: the first aimed to discuss theories and research on topics such as the role of English, technology and education; the second was devoted to developing lesson plans with the assistance of the supervising professor and the professor assistant (authors of this study) and the third aimed at the presentation of lesson plans and feedback from peers and supervising professor and the professor assistant. Throughout the modules, BL activities were planned for both face-to-face and online environments taking into account BL principles such as the offer of a variety of learning options, complimentarity of the environments and contextuality as shown in Table 2. 
Table 2: Online and Face-To-Face Activites

\begin{tabular}{|l|l|l|}
\hline & \multicolumn{1}{|c|}{ Face-to-face } & \multicolumn{1}{c|}{ Online } \\
\hline $\begin{array}{l}\text { Module 1 } \\
\text { August and } \\
\text { September }\end{array}$ & $\begin{array}{l}\text { Discussions of mandatory reading } \\
\text { list on various topics, including the } \\
\text { role of digital technology in } \\
\text { education }\end{array}$ & $\begin{array}{l}\text { Discussion questions for required reading. } \\
\text { Relate discussions to proposed videos and images } \\
\text { Summarize text collaboratively using the GoogleDocs } \\
\text { tool. } \\
\text { Synthesize text ideas through online mind mapping tools. }\end{array}$ \\
\hline $\begin{array}{l}\text { Module 2 } \\
\text { (October 2016) }\end{array}$ & Creating lesson plans in groups & $\begin{array}{l}\text { Inverted Classroom: Students should watch a video } \\
\text { presenting tools to use to create lesson plans in the } \\
\text { classroom environment. } \\
\text { Share lesson plans in progress. } \\
\text { Review and give feedback on ongoing peer planning. } \\
\text { Create webquests that will be used in the planned classes. }\end{array}$ \\
\hline $\begin{array}{l}\text { Module 3 } \\
\text { November } \\
\text { and December } \\
\text { 2016) }\end{array}$ & $\begin{array}{l}\text { Presentation of lesson plans } \\
\text { through microteaching }\end{array}$ & $\begin{array}{l}\text { Share webquests, reflections, self-assessment and } \\
\text { feedback on presentations. } \\
\text { Create an e-portfolio with all the reflections and all the } \\
\text { material produced during the course. }\end{array}$ \\
\hline
\end{tabular}

Source: the authors'

For the online environment, a group was created in the social network Facebook, due to the familiarity that Brazilians have with it (FINARDI; PORCINO, 2016) and the fact that pre-service teachers already had accounts there. After presenting the proposal for the BL intervention to the preservice ELT teachers, they were asked to join the Facebook group restricted to the researchers/professors and students enrolled in that course. Participants were expected to fulfill the tasks they were instructed online and to interact in the community as part of their assessment of the course. Interactions were mediated by the researchers/professors, and students were encouraged to actively participate online throughout the semester.

Most of the activities proposed were planned and developed according to the constant observation of interactions and feedback from the students/participants (ELT pre-service teachers enrolled in the practicum course). In addition to the activities described, students were encouraged to share contents relevant to the topics discussed, positioning themselves in the group. For that, the professor assistant offered online support to help with the topics related to the integration of digital technologies in the lesson plans. In addition, the virtual environment served as a space for the dissemination of events of interest, announcements related to classroom schedule and planning and as text/contents repository.

Regarding the profile of the participants, there were six female and three male students with age ranks from 21 to 54 years old. Eight of the nine students had had some ELT experience prior to the course and all had Facebook accounts. Data stems from pre-service teachers' responses to questionnaires with open and closed questions and observations of the professors in charge of the course and the pedagogical intervention, both of the interaction in the online environment and in class. After a preliminary content data analysis, data was categorized into three overarching themes analysed mostly qualitatively. In what follows the main findings will be reported with the ensuing discussion of data.

\section{FINDINGS AND DISCUSSION}

\section{Digital Technologies Use by Pre-Service Teacher}

As reported in the questionnaires administered in the beginning of the course, all participants had home access to internet, smartphones and used the internet every day. Contents published in the online group were viewed by most participants in less than 24 hours, regardless of the day or time of publication. Replies to post by participants also happened in a short period of time thus allowing us to say that the shortening of spatial and temporal distances (LÉVY, 1999, CÁRDENAS-ROBLEDO; PEÑA-AYALA, 2018) through the use of cell phones and the constant connection between the participants allowed last-minute notices and communications regarding changes in the course plan, due 
to several intercurrences (stoppages, occupations, strikes, events), which were quickly communicated to all students involved in the online group.

Regarding online behavior and preferences, sites on news, social interaction and videos were the most popular among participants who considered themselves experts in searching and locating information online as well as in editing documents, using the online interface and security. Moreover, participants declared they made optional use of online teaching resources for their classes and academic life, such as using translation tools, dictionaries, worksheet websites and public lesson plan ideas.

By looking at the nature of their digital practices for academic and professional purposes, we interpret that they had a passive role in the online environment, focused on its operational use. Also, content was produced only unilaterally as in the Web 1.0 by just receiving and reproducing information/contents. Collaborative practices in which content is created bi/multilaterally by participants were not observed.

On the other hand, participants did not see themselves as mere observers as they reported being engaged in interactions either by responding to posts or spontaneously sharing information, specially on Facebook. For that, an unexpected result was the observation that the engagement of participants with Facebook was considerably different in practice (as observed in the interactions in the Facebook group) and in theory, as reported by them in the questionnaire, as shown in Image 1.

IMAGE 1 - Interaction of pre-service teachers in Facebook according to initial questionnaires

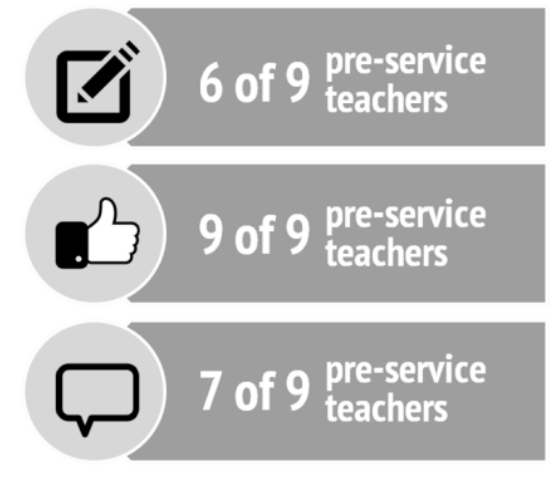

Source: the authors'

As previously stated, this study aimed at integrating digital technologies through the creation of an online learning environment for pre-service teachers as an interactive and collaborative space that would contribute to breaking the teacher focused traditional education paradigm. To this end, the creation of a Facebook group was found to be an opportunity to decentralize the knowledge construction by using a commonly used social network to expand perspectives of pre-service teachers on educational practices, as suggested by Finardi and Porcino (2015) and Rabello (2015).

By offering a space for discussion and integration of digital technologies in a BL environment it was hoped that pre-service teachers would develop their autonomy in moving from the operational to more critical dimensions of the integration of digital technologies in education. These expectations were clearly informed in the beginning of the course and emphasized both during face-toface classes and in the online environment.

Of the 80 posts made in the Facebook group, only 7 were published by the pre-service teachers, in other words, $91 \%$ of posts were made by the professors and only $9 \%$ by the pre-service teachers. As for re-active participation, nonverbal responses, such as "likes", and verbal ones as in commentaries to the posts were balanced between pre-service and professors as we can see in Image 2 . 
IMAGE 2 - Professors and pre-service teachers' behavior in Facebook during the semester

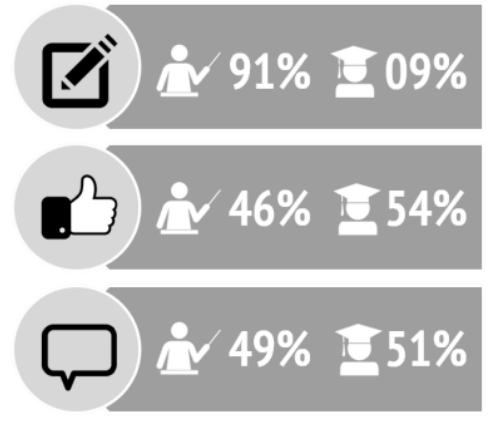

Source: the authors'

However, if we consider that there were nine pre-service teachers and only three professors, we notice that responsive participation, both verbal and non-verbal, was an average of $5 \%$ for each preservice teacher against an average $16.5 \%$ for each professor. This suggests a considerable level of passivity by the majority of pre-service teachers in the online environment. In fact, we see in excerpts from the final questionnaries that participants even expressed some rejection to the online environment chosen, contradicting their reports in the initial questionnaires. One possible explanation for this is that they may have perceived Facebook mostly as a social network (entertainment) tool, ignoring its educational/academic/pedagogical potential, something already reported in the literature (for example ARRUDA, 2013; FINARDI; PORCINO, 2016).

Regarding the response rate for pre-service teachers to posts made in the group, only $35 \%$ of them received comments from a different participant than the one who published the content. On the other hand, $59 \%$ of the publications were "liked" by pre-service teachers. As one of the intented outcomes for the online environment was to contribute to an active and collective learning by the preservice teachers, we consider that this was minimally achieved.

Most pre-service teachers reported being satisfied with their own participation and involvement in the online group, unlike the professors who clearly expected more involvement suggesting a gap between pre-service teachers and professors' expectations for the BL intervention.

The observation and analysis of the context where the pegagogical intervention was carried out can point to some possible factors that hindered a more active participation of pre-service teachers. We believe that the fact they were in the final months of their graduation, they lacked time and motivation to handle all course assignments in the semester. Also, it is important to mention that during that semester, there was a turmoiled political conjecture regarding the approval of bills for high school reform and for government expenditure change of rules that impacted investiment in education. As a protest against those government measures, from October to December 2016, there were several demonstrations all over Brazil. In the State of Espirito Santo, where this research endeavour took place, students occupied the building of their schools and university and professors went on strike leading to the suspension of many classes.

\section{New Skills, Practices and Ways of Thinking}

Considering that engagement is a result of the educational values and ways of thinking, a predominance of the traditional paradigm of education was observed throughout the study, as illustrated in the excerpts below:

Participant 2: I believe that the teacher did not know how to explore this [connection of technology with the students' reality] in the best possible way [...] Perhaps if the activities were a little more dynamic, they would have been even more interesting.

Participant 3: [...] I am not convinced that the online component has been adequately explored. Participant 6: [...] the face-to-face classes could have been better used [...] it was necessary to work more with the reality of the teaching English in public schools. 
From the pre-service teachers' perspective, even though they knew what should be done (in this example, discussing what happens at public schools), they did not make or propose any move in that direction as they understood that was the decision and responsibility of the professor in charge of the course.

Another evidence of strong attachment to the pre-digital paradigm is the lack of synergy in content production. Students were divided in groups to create lesson plans and were asked to share their lesson plan drafts on the online environment for feedback and collaboration. However, feedback and collaboration were not observed online. Similarly, in the end of the semester, students had to send the webquests they had created to the professor and they were asked to also share them in the online environment so that all students could see their final work. Once again, no feedback or collaboration was observed online.

On the one hand, there was an apparent difficulty in integrating digital technologies into education in their cultural dimension through active involvement of the pre-service teachers in social practices and criticism through the transformation of practices. On the other hand, as for the instrumental dimension, pre-service teachers confirmed reports of the initial questionnaire when showing a certain ability and seemed to have very few technical difficulties during the execution of the proposed activities.

During the execution of collaborative writing activities using GoogleDocs and in the production of webquests, it was possible to observe the technical knowledge that pre-service teachers had with online text editing tools, the search and selection of available tools and contents and the creation of presentations using multimodal resources to achieve the proposed pedagogical objectives. In fact, preservice teachers seemed to be more interested in operational aspects of digital technologies, showing a contrast between the objectives of the professors of the discipline and that of the pre-service teachers.

Regarding the general engagement of pre-service teachers in the online environment, it happened mostly for the negotiation of matters concerning face-to-face classes. Indeed, the event with most engagement and meaningful participation was related to the negotiation of course calendar/planning as a result of the strike as can be seen in Image 3.

Image 3-Online interaction

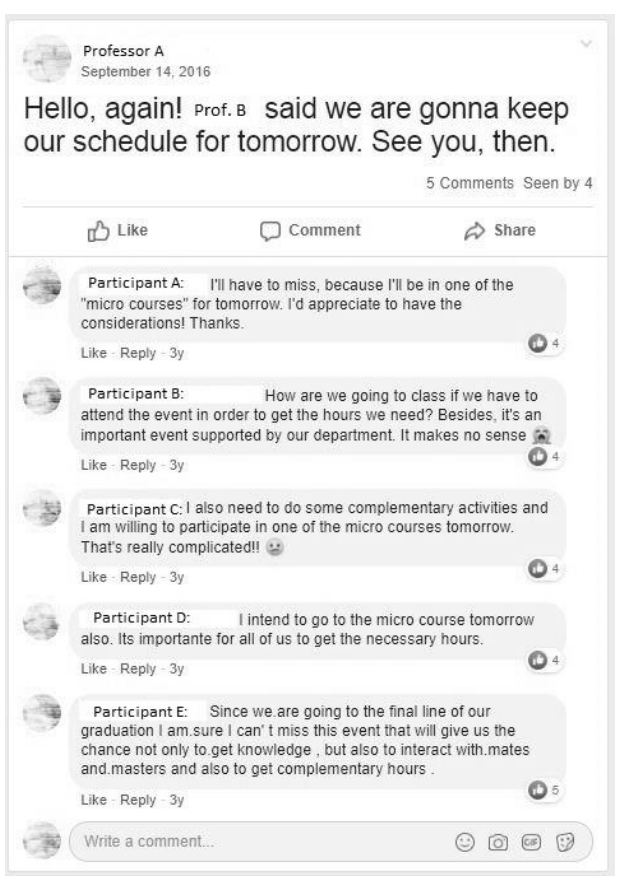

Source: https://www.facebook.com/groups/1140994509307169/

When the professor posted a notification informing the continuity of classes despite an important event promoted by the Language Department, pre-service teachers promptly argued for the 
need to participate in the event asking the professor to consider cancelling/rescheduling that class. On that occasion, pre-service teachers knew exactly how to use the resourcers available in the online environment (comments, "likes", emojis) to make themselves heard, defend their common interests and bring about a change in reality (class programation).

Although this was the only time when most participants really engaged in the online environment, there were other episodes in which it was possible to notice how students' interaction brought about changes. In the example below, taken from a discussion proposed by the professors about English teaching, it was possible to see how the exchange of experiences and opinions could lead to critical reflection and a possible transformation of the teaching practice of the participants involved.

Image 4 - Online interaction

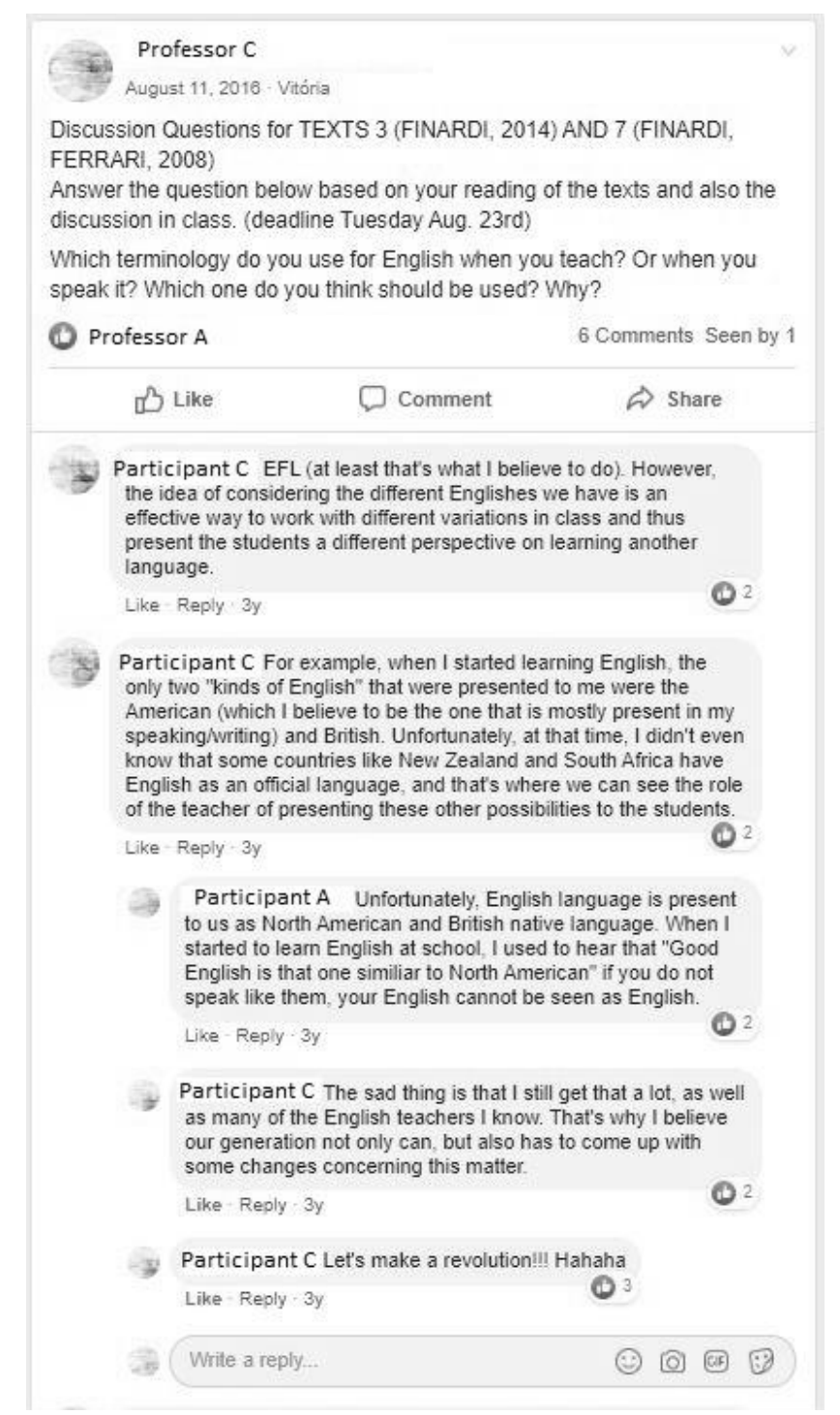

Source: https://www.facebook.com/groups/1140994509307169/

Another example worth mentioning was a dialogue between the same participants about using cell phones in the classroom, as shown in Image 5. 
Image 5 - Online interaction

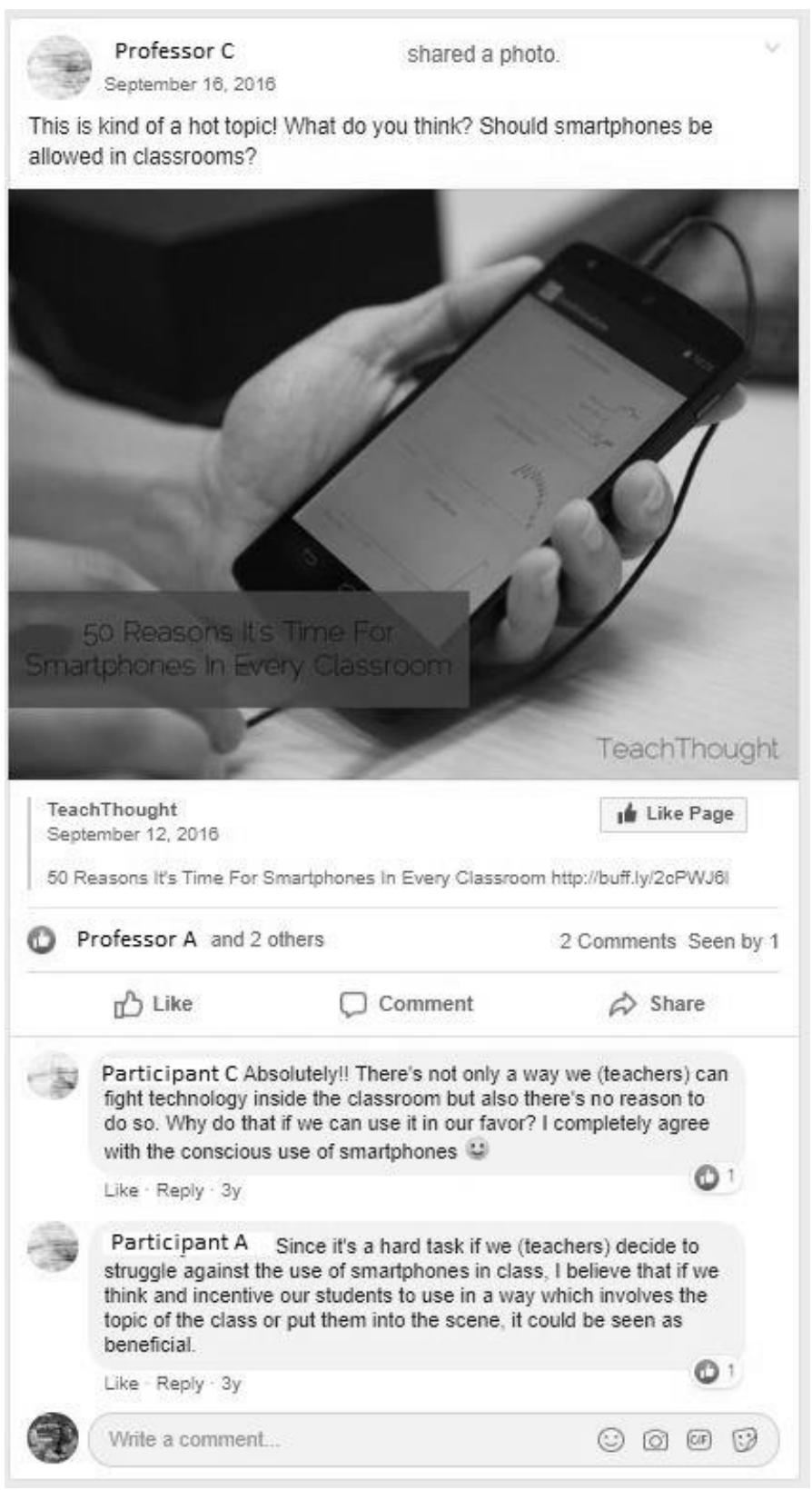

Source: https://www.facebook.com/groups/1140994509307169/

We can see that both participants appreciated the use of cell phones for pedagogical purpose. By understanding pedagogical practices as flexible and able to adapt to the presence of cellphones, they showed the importance of cultural and critical aspects of digital technology integration to education. Overall, pre-service teachers seemed to follow the traditional, hierarchical and centralized logic of education most of the time, in the mindsets continuum proposed by Lankshear and Knobel (2007), they seemed to be operating on the "tension between materiality and nonmateriality" as highlighted by Ferraz (2014, p. 61).

\section{Blended Learning in ELT Education}

Part of the objective of this study was to design and implement a BL intervention that would contribute to a change in pedagogy whereby the student, in this case pre-service teachers, actively 
learnerd through the mediation of digital technologies (GRAHAM, 2006; MATHEOS; DANIEL; MCCALLA, 2012). One fact that may have determined the results of this study is related to the choice of Facebook as the online environment. As previously observed in Finardi and Porcino (2016), participants in this study did not perceive social networks as a place for learning, as can be seen in the excerpts below:

Participant 4: A moment that I used to use as a distraction ended up becoming an obligation. [...] I don't know if it was because it was on Facebook [...], but, as I mentioned, I didn't feel encouraged.

Participant 9: [Facebook] is a good way of communication, but to discuss texts it was a little vague. [...] I would rather talk in class than comment on Facebook.

It seems that participants did not perceive Facebook as an environment for learning. We wonder if using a website created for educational objectives, such as Edmodo (FADINI; FINARDI, 2015) would enable more participation of pre-service teachers. Perhaps future research could tell?

Matheos, Daniel and McCalla (2012) and Sharma and Westbrook (2016) had already warned us of the alleged preference for face-to-face learning suggesting it is the result of lack of preparation to become autonomous learners. According to the aforementioned authors, students need time and support to assume this leading role. BL has the potential to facilitate this support by providing more personalized attention to each student (LEFFA, 2012) as noticed in the present study in several interactions that provided a space for pre-service teachers to request information, clarify doubts and ask for support according to their needs.

Whittaker (2013) suggests that the lack of motivation for active participation in BL environments may be related to the type of content and the cognitive level required. Despite the limitations of BL in terms of engagement, it contributed to the development of pre-service teachers' digital literacy and to critically think about digital technologies adaptation to cultural, social and other contexts in their own future teacher practice.

Considering that this experience was the first contact of pre-service teachers with $\mathrm{BL}$, we agree with Whittaker (2013) that the less familiar with the approach and the new practices, the more resistant participants are to become an insider. For that reason, it is important to keep in mind that participation in affinity groups is not automatic and generally begins with more peripheral participation and with time progresses to a more central role in the community (MILLS, 2010). In fact, at the end of the semester, a participant made a spontaneous post by sharing a resource and his own idea of how to use it in the classroom.

Another contributions BL made to ELT education was the possibility of an alternative environment that allowed the continuity of the subject even with the cancellation of face-to-face lessons. Finally, even though the BL intervention aimed at a "transforming blend" (GRAHAM, 2006) to promote a change of pedagogy into a model where students are active knowledge builders through technologyenabled interactions, this was not observed. What was perceived, instead, was a more "enhancing blend" (GRAHAM, 2006) with some superficial changes in pedagogy, through the sharing of online resources and the incorporation of some knowledge-building practices in which pre-service teachers engaged.

In order to evaluate the approach implemented and the possible reasons for the dificulty in reaching the transformation goal, the conceptual framework for BL evaluation proposed by Wong, Tatnall and Burgess (2014) based on the aspects of readiness, intensity of adoption and impact was used.

As for readiness, we looked into three spheres: institution, teachers and students. Regarding the institution, we can consider that it was suitable for implementation since the approach was made in an experimental way in the course and that the institution had a computer lab that allows the connection of participants if they were unable to do so outside the university. Although the internet connection in the classroom was unreliable, all online activities were scheduled to be done outside of classroom. Regarding professors, despite previous preparation and instrumental knowledge of the digital technologies, professors were not successful at proposing stimulating practices for the BL environment. Regarding students, they seemed to be far from prepared for the BL approach used which demanded engagement and extra-class activity-time. In addition, we noticed a lack of cultural preparation by the pre-service teachers to accept the online environment as a learning opportunity. 
As for the intensity, we noticed that the learning options offered to the participants were not many. In the traditional modality, only the option of face-to-face lessons was offered and for the new (online) modality, interactions through social network were the only form available.

Finally, in relation to the impact of the approach, that is, its influence on the quality of learning, we can say that, from the point of view of the participants, the level of satisfaction was reasonable and most believe that the approach contributed to their teacher education. From the perspective of the professors, it fell short of their expectations.

\section{FINAL THOUGHTS}

The present study found that blended learning can be limited by the lack of active participation from students, which in turn may result in poor educational models when it comes to teacher education courses. Also, it seems that when environments do not complement each other, they do not strengthen one another causing, instead, an idea of substitution rather than that of complementation. Most importantly, BL initiatives can be seriously impaired if the online mode is not valued as a learning environment, as was the case with the Facebook group in this study.

Understanding education as ubiquitous and unrestrained to face-to-face classroom environments is essential to the readiness required for the educational possibilities of online environment, especially social networks. However, it seems that the Brazilian culture still has a strong attachment to the traditional paradigm of education, in which the institution and the teacher deposit knowledge in the student, who in turn, plays a passive and receptive role with a mindset that is not consistent with the digital society.

Nevertheless, BL, when appropriated by teachers and students, has found to contribute to breaking with the traditional education paradigm. In this study, there were few events of true engagement observed along the course, but it was possible to see pre-service teacher empowerment when trying to negotiate with their professors for the cancellation of the face-to-face classes. They did so because they understood that they were capable to fight for their interests using all the tools enabled by the online environment.

Another contribution observed for blended learning was the creation of a more personal communication channel between teacher and students who felt comfortable asking for assistance outside face-to-face classroom hours. Also, due to the interruption of face-to-face classes because of teacher and student strikes, it was possible to continue the course and the interaction between students and teachers until the end of the academic period, making teaching more flexible. Thus, we understand that the implementation of a BL approach can provide pre-service teachers with new educational experiences that may favor reflective teacher education in relation to the integration of digital technologies in teaching and learning practices.

\section{ACKNOWLEDGEMENT}

Kyria Rebeca Finardi wishes to thank Cnpq for research support (Bolsa de Produtividade em Pesquisa PQ).

\section{REFERENCES}

ARRUDA, E. P. Ensino e aprendizagem na sociedade do entretenimento: desafios para a formação docente. Educação, v. 36, n. 2, p. 232-239, 2013.

CÁRDENAS-ROBLEDO, L. A., PEÑA-AYALA, A. Ubiquitous learning: A systematic review. Telematics and Informatics, v. 35, n. 5, p. 1097-1132, 2018. DOI https://doi.org/10.1016/j.tele.2018.01.009 
DZIUBAN, C., GRAHAM, C. R., MOSKAL, P.D. et al. Blended learning: the new normal and emerging technologies. International Journal of Educational Technology in Higher Education, v. 15, n. 3, p. 1-16, 2018. DOI https://doi.org/10.1186/s41239-017-0087-5

FADINI, K. A. Formação Inicial de Professores de Inglês do e para o Século XXI: os papéis da língua inglesa e da tecnologia digital. Dissertação de Mestrado em Linguística, Programa de PósGraduação em Estudos Linguísticos, Universidade Federal do Espírito Santo, Vitória, 2016.

FADINI, K.; FINARDI, K. R. Affordances of Web 2.0 Interfaces for the Teaching/Learning of L2 in The Flipped Classroom. In: International Conference of Education, Research and Innovation, 2015, Sevilha. ICERI 2015 Proceedings. Madri: Iated, 2015. v. 1. p. 1052-1058.

FERRAZ, D. M. Novos letramentos e educação de línguas estrangeiras: problematizações e desafios. In: STELLA, P. R.; CAVALCANTI, I.; TAVARES, R.; IFA, S. (Orgs.). Transculturalidade e De(s)colonialidade nos Estudos em Inglês no BraZil. 1ed. Maceió: Edufal, 2014, p. 53-84.

FINARDI, K. R.; PORCINO, M. C. Facebook na ensinagem de inglês como língua adicional. In: ARAÚJO, J.; LEFFA, V. (Orgs.). Redes sociais e ensino de língua: o que temos de aprender. 1ed. São Paulo: Editorial Brasileira Comercial, 2016, v. 1, p. 99-115.

FINARDI, K. R.; PORCINO, M. C. O Papel do Inglês na Formação e na Internacionalização da Educação no Brasil. Revista Horizontes de Linguística Aplicada, v. 14, p. 109-134, 2015.

FINARDI, K. R.; PORCINO, M. C. Tecnologia e Metodologia no Ensino de Inglês: Impactos da Globalização e da Internacionalização. Ilha do Desterro, Florianópolis, v. 1, n. 66, p. 239-283, 2014.

FINARDI, K. R.; PREBIANCA, G. V. V.; MOMM, C. Tecnologia na educação: o caso da internet e do inglês como linguagens de inclusão. Revista Cadernos do IL, Porto Alegre, n. 46, p. 193-208, 2013

GRAHAM, C. Blended Learning Systems: Definition, Current Trends, Future Directions. In: BONK, C. J.; GRAHAM, C. R. (Orgs.). Handbook of Blended Learning: Global perspectives, local designs. San Francisco, CA: Pfeiffer Publishing, 2006. p. 41-54.

GRAHAM, C. R, ALLEN, S., URE, D. Benefits and challenges of blended learning environments. In: KHOSROW-POUR, M. (Org.), Encyclopedia of information science and technology. Hershey, PA: Idea Group, 2005, p. 253-259.

GRAHAM, C. R.; WOODFIELD, W.; HARRISON, J. B. A framework for institutional adoption and implementation of blended learning in higher education. The internet and higher education, v. 18, p. 4-14, 2013.

GRUSZCZYNSKA, A.; MERCHANT, G.; POUNTNEY, R. Digital Futures in Teacher Education: Exploring Open Approaches towards Digital Literacy. Electronic Journal of e-Learning, v. 11, n. 3, p. 193-206, 2013.

JOHNSON, L.; ADAMS BECKER, S.; ESTRADA, V.; FREEMAN, A. NMC Horizon Report: 2015 K-12 Edition. Austin, Texas: The New Media Consortium, 2015.

KEENGWE, J.; KANG, J. A review of empirical research on blended learning in teacher education programs. Education and Information Technologies, v. 18, n. 3, p. 479-493, 2013. 
LANKSHEAR, C.; KNOBEL, M. Researching new literacies: Web 2.0 practices and insider perspectives. E-Learning and Digital Media, v. 4, n. 3, p. 224-240, 2007.

LANKSHEAR, C.; SNYDER, I.; GREEN, B. Teachers and technoliteracy: Managing literacy, technology and learning in schools. Sydney: Allen and Unwin, 2000.

LEFFA, V. Ensino de línguas: passado, presente e futuro. Revista de Estudos da Linguagem, v. 20, n. 2, p.389-411, 2012.

LÉVY, P. Cibercultura. Tradução de Irineu da Costa. São Paulo: Editora 34, 1999.

MATHEOS, K.; DANIEL, B. K.; MCCALLA, G. I. Dimensions for blended learning technology: Learners' perspectives. Journal of Learning Design, v. 1, n. 1, p. 56-76, 2012.

MERLO, M. C. R.; FERRAZ, D. M. Letramentos e formação docente para o ensino de inglês. In: TOMAZI, M. M. ; ROCHA, L. H. P.; FERRAZ, D. M. (Orgs.). Estudos linguísticos: descrição, texto, discurso e ensino. Vitória: Editora do Programa de Pós-graduação em Estudos Linguísticos, 2016, v. 1, p. 265-278.

MILLS, Kathy Ann. A review of the "digital turn" in the new literacy studies. Review of educational research, v. 80, n. 2, p. 246-271, 2010.

MONTE MÓR, W. M. Foreign languages teaching, education and the new literacies studies: expanding views. In: GONÇALVES, G. R.; ALMEIDA, S. R. G.; PAIVA, V. L. M. O.; RODRIGUES-JUNIOR, A. S. (Orgs.). New Challenges in Language and Literature. Belo Horizonte: FALE/UFMG, 2009, p. 177-189.

NORTON, Lin. Action research in teaching and learning: A practical guide to conducting pedagogical research in universities. Routledge, 2018.

PAIVA, V. L. M. O. A formação do professor para uso da tecnologia. In: SILVA, K. A.; DANIEL, F. G.; KANEKO-MARQUES, S. M.; SALOMÃO, A. C. B. (Orgs.). A formação de professores de línguas: Novos Olhares. Campinas, SP: Pontes Editores, 2013, p. 209-230.

RABELLO, C. Interação e aprendizagem em Sites de Redes Sociais: Uma análise a partir das concepções sócio-históricas de Vygostky e Bakhtin. Revista Brasileira de Linguística Aplicada, v. 15, n. 3, p. 735$760,2015$.

RADA, J. Oportunidades e riscos das novas tecnologias para a educação. In: TEDESCO, J. C. (Org.). Educação e novas tecnologias: esperanças ou incertezas? Tradução de Cláudia Berlier, Silvana Cobucci Leite. São Paulo: Cortez, 2004, p. 109-119.

SHARMA, P.; WESTBROOK, K. Online and blended language learning. In: FARR, F.; MURRAY, L. (Orgs.) The Routledge handbook of language learning and technology, Routledge: Londres e NY, 2016. p. 320-333, 2016.

TEIXEIRA, D.; FINARDI, K. TICs no ensino presencial: evidências de um curso de formação continuada na Universidade Federal do Espírito Santo. Revista (Con)textos Linguísticos, v. 7, p. 7996, 2013.

WARSCHAUER, M. Of digital divides and social multipliers: Combining language and technology for human development. Information and communication technologies in the teaching and learning 
of foreign languages: State of the art, needs and perspectives. Moscow: UNESCO Institute for Information Technologies, 2004.

WHITTAKER, C. Introduction and Conclusion. In: TOMLINSON, B.; WHITTAKER, C. (Orgs.). Blended Learning in English Language Teaching. London: Brithish Council, 2013. p. 9-23; 223-242

WONG, L.; TATNALL, A.; BURGESS, S. A framework for investigating blended learning effectiveness. Education+Training, v. 56, n. 2/3, p. 233-251, 2014.

Submetido: $19 / 02 / 2020$

Aprovado: 03/07/2020 